\title{
The Microbial Flora of Broiler-house Litter and Dust
}

\author{
By C. DENNIS AND JENNIFER M. GEE \\ A.R.C. Food Research Institute, Colney Lane, Norwich, NOR $70 F$
}

(Received I9 February I973; revised 6 April I973)

\begin{abstract}
S U M M A R Y
A survey of litter samples from broiler houses at widespread localities in the U.K. revealed a significant difference between the fungal floras before and after the houses had been used for a single crop of birds. Paecilomyces varioti, Trichoderma spp. Aureobasidium pullulans, and Hyalodendron lignicola predominated in the fresh litter, but were replaced by Scopulariopsis brevicaulis and Aspergillus spp. in the final samples. The fungi present in the final litter samples were also found in the initial and final dust samples, indicating that the dust is a potential source of inoculum. These results are discussed in relation to the formation in broilerhouse litter of 2,3,4,6-tetrachloroanisole (a compound associated with a musty taint in chickens), and to the potential formation of mycotoxins.
\end{abstract}

\section{INTRODUCTION}

Curtis et al. (1972), reported a musty taint in broiler chickens and showed that it was caused by 2,3,4,6-tetrachloroanisole. Evidence was obtained that this anisole is formed by the microbiological methylation of 2,3,4,6-tetrachlorophenol, and three fungal species isolated from litter associated with musty birds were shown to be capable of methylating this phenol. Published information about the microbial flora of broiler-house litter is restricted to the reports of Halbrook, Winter \& Sutton (I95I), Schefferle (1965) and Lovett, Messer \& Read (I971). Only the last authors examined the fungal flora in any detail, and then carried identification only to the generic level. The present survey was undertaken to determine the fungal flora of broiler house litters and to establish whether the flora of litters containing 2,3,4,6-tetrachloroanisole and giving rise to musty birds is unusual.

\section{METHODS}

\section{Samples of litter and dust}

Samples of litter and dust were taken from 3I broiler houses at different localities in the United Kingdom (Cambridgeshire, Co. Durham, Essex, Hertfordshire, Lincolnshire, Norfolk, Sussex, Wiltshire, Yorkshire and Aberdeenshire) before and after they had been used for a single crop of birds. The average time for a crop of birds to be in a broiler house was 56 days. The huts sampled were heated in three ways: viz. with brooder heaters in a single longitudinal bank down the centre of the hut (type A); in two or more parallel longitudinal banks (type B); or by hot air blown into the hut from one end (type C) (Fig. I). When the chicks are initially placed in either of hut types A or B they congregate beneath the heaters whereas in type $C$ their movement is restricted by a movable curtain. In hut types A and B samples were taken from each square yard of a rectangular area of approximately 30 sq yards (i.e. 30 samples), covered by 500 to 600 birds. The width of these huts differed; the area sampled always extended from the centre of the hut to the side wall, 
A

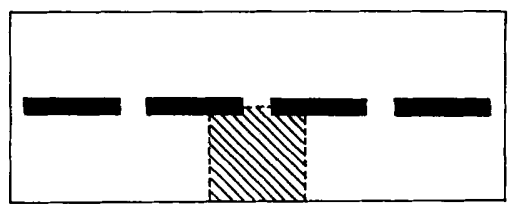

B

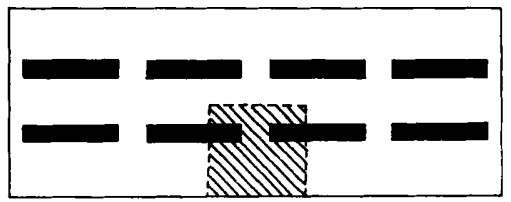

C
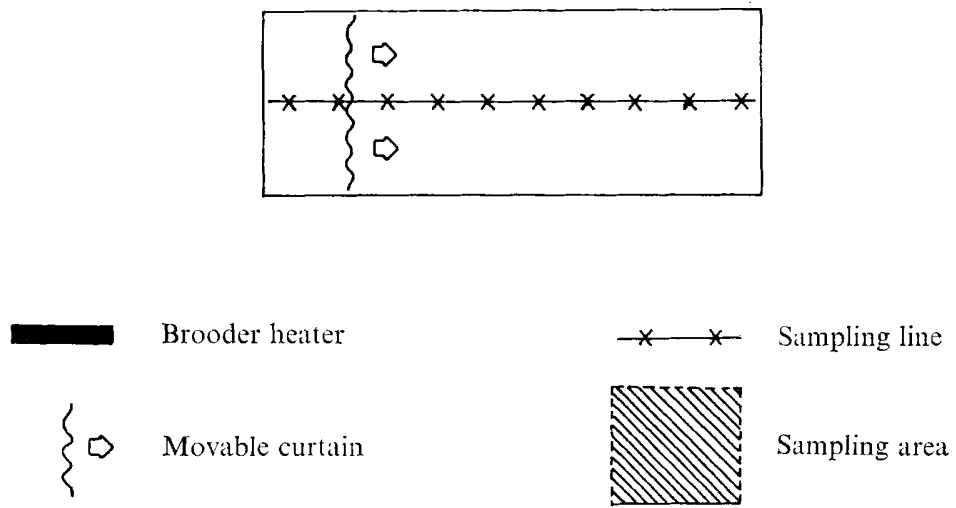

Fig. I. The position of sampling areas in the three types of broiler houses.

midway along the length of the hut. In huts of type C, 30 samples were taken at approximately equal intervals along a central line from one end to the other. Each sample was taken through the whole depth of the litter. The combined sample from each hut weighed approximately 2.0 to $3.0 \mathrm{~kg}$ for fresh litter and approximately 4.0 to $5.0 \mathrm{~kg}$ for used litter. Where available, samples of dust of at least I $\mathrm{g}$ were taken from beams and ledges above the area used for sampling the litter. All samples were collected in unused, clean polythene bags and mixed by shaking thoroughly before mycological examination and moisture determinations. The average air temperature in the broiler house at the end of the rearing cycle was $19.5^{\circ} \mathrm{C}$. Litter temperatures were not recorded, but in a previous similar survey they were approximately $5{ }^{\circ} \mathrm{C}$ higher than the corresponding air temperatures.

Samples of litter associated with musty birds were those used in previous work (Curtis et al. 1972) and were examined at that time.

\section{Isolation and identification of organisms}

All samples of litter and dust were treated as follows. Each of three $0.5 \mathrm{~g}$ portions was added to Io $\mathrm{ml}$ of a sterile $0 . \mathrm{I} \%(\mathrm{v} / \mathrm{v})$ solution of Tween 80 in I oz Universal square-based masticator bottles and macerated for I $\min$ by a M.S.E. masticator (Measuring and Scientific Equipment, London). Samples (O.I ml) of appropriate dilutions were spread over the whole surface of dried agar plates. The following media were used: ( 1 ) $2 \%$ Difco Bacto malt extract (Difco Laboratories, West Mclesey, Surrey), $\mathrm{pH} 4.0$, solidified with $2 \%$ Davis New Zealand Agar. The agar was autoclaved separately to avoid breakdown at acid $\mathrm{pH}$. (2) Oxoid Sabouraud Dextrose agar (Oxoid Ltd, London), $\mathrm{pH} 5 \cdot 6$, containing I $2 \mu \mathrm{g} / \mathrm{ml}$ of penicillin and $40 \mu \mathrm{g} / \mathrm{ml}$ of streptomycin sulphate. (3) $2 \cdot \mathrm{I} \%$ Difco Bacto YM broth, pH 3.4, solidified with $2 \%$ Davis New Zealand Agar (Davis Gelatine Ltd, Warwick). The agar was 
autoclaved separately to avoid breakdown at acid pH. (4) Difco Bacto Heart Infusion Agar, $\mathrm{pH} 7 \cdot 4$.

Viable mould counts were made on media I and 2 and viable yeast counts on medium 3, after 5 days of incubation at $25{ }^{\circ} \mathrm{C}$. Total viable bacterial counts were made on medium 4 after 2 and 4 days of incubation at $37^{\circ} \mathrm{C}$ and $25^{\circ} \mathrm{C}$ respectively. The presence of one colony on the lowest dilution plate corresponded to a count of 200 viable units/g of litter or dust.

The moulds were identified as far as possible, usually to the genus, on the isolation plates. Representative colonies including those which could not be identified on the isolation plates, were subcultured, purified and stored on Difco Bacto Malt Extract agar slopes at I ${ }^{\circ} \mathrm{C}$ before further identification. All isolates were grown on malt extract agar for identification. Aspergillus spp. and Penicillium spp. were also grown on Czapek Dox agar, containing either $3 \%$ or $20 \%$ sucrose.

\section{Determination of moisture contents of litter}

The moisture content of samples of fresh shavings and used litter was determined by drying $5 \mathrm{~g}$ and $20 \mathrm{~g}$ samples respectively to constant weight at $120^{\circ} \mathrm{C}$.

\section{RESULTS}

The micro-organisms found in the initial and final samples of litter and dust are shown in Tables $I$ and 2. The mean total fungal count (viable units/g) of all the initial litters was slightly lower than that of the final samples of litter. By contrast there was little difference between the initial and final dust samples, but the counts for the dust were consistently higher than those for the litters. More bacteria were present in the dust than in the litter. The bacterial counts were similar at $25{ }^{\circ} \mathrm{C}$ and $37^{\circ} \mathrm{C}$ except that with four samples of dust no bacteria grew on plates incubated at $37^{\circ} \mathrm{C}$ although the count at $25^{\circ} \mathrm{C}$ exceeded $10^{6} / \mathrm{g}$. The total bacterial counts of the initial and final samples of dust were similar, but the count for the final litter samples was consistently higher than that of the initial litter samples (cf. Schefferle, 1965). The total yeast count was similar in both the initial and final samples of litter and dust.

The majority of dust samples had a different fungal flora from that of the initial litter. Aspergillus spp. especially $A$. sydowi, $A$. repens and $A$. candidus, and Scopulariopsis brevicaulis predominated in the dust, while Paecilomyces varioti, Trichoderma spp., Aureobasidium pullulans and Hyalodendron lignicola were most abundant in the fresh litter. Penicillium spp. were present in over $90 \%$ of initial litter and dust samples. Where Aspergillus spp. and $S$. brevicaulis were detected in the fresh litter the counts were much lower than in the dust.

The mould flora of the final litter, collected after the birds had been on the litter for between 52 and 77 days, was very different from that of the initial shavings. Aureobasidium pullulans, Trichoderma spp. and Hyalodendron lignicola were not found in the final litter, and there was a marked decrease in the incidence of Paecilomyces varioti. Although the shavings may be diluted up to ten-fold by the faeces, between initial and final sampling (L. J. Parr, M. G. Gee, D. G. Land and D. Robinson, unpublished), dilution alone does not account for the above observations. Aspergillus spp. and Scopulariopsis brevicaulis predominated in the final litter samples. Of the former, $A$. sydowi, $A$. repens and $A$. candidus occurred most frequently, while $A$. ruber and $A$. chevalieri were found in approximately $50 \%$ of the samples and A. versicolor, A. amstelodami, and A. flavus in $25 \%$ of the samples. The combined count for Penicillium spp. was less in the final litter than initially but $P$. crustosum still remained the predominant member of the genus. Absidia cylindrospora and 
Table I. Microbial flora of poultry litter and dust: initial samples

The Penicillium species isolated from the shavings included $P$. crustosum, $P$. brevicompactum, $P$. notatum, $P$. roqueforti, $P$. frequentans, $P$. waksmani, $P$. janthinellum, $P$. nigricans, $P$. corylophilum, $P$. citrinum, $P$. carneo-lutescens, $P$. viridicatum, $P$. lanosum, and $P$. funiculosum, while $P$. crustosum, $P$. brevicompactum, $P$. chrysogenum, $P$. notatum, $P$. frequentans, and $P$. waksmani were isolated from the dust samples.

\begin{tabular}{|c|c|c|c|c|}
\hline & Shavings & Dust & Shavings & Dust \\
\hline Total no. of samples & $3 I$ & 24 & - & - \\
\hline \multicolumn{5}{|l|}{ Fungal species } \\
\hline Aspergillus sydowi & 6 & 24 & $8.0 \times 10^{2}$ & $7 \cdot 3 \times 10^{6}$ \\
\hline A. versicolor & 3 & 8 & $7 \cdot 2 \times 10^{2}$ & $7.0 \times 10^{5}$ \\
\hline A. repens & 4 & 20 & $4.0 \times 10^{2}$ & $6.0 \times 10^{6}$ \\
\hline A. amstelodami & I & 4 & $6.0 \times 10^{1}$ & $2.5 \times 10^{6}$ \\
\hline A. ruber & 0 & 9 & - & $7.0 \times 10^{6}$ \\
\hline A. chevalieri & I & II & $6.0 \times 10^{3}$ & $7.0 \times 10^{5}$ \\
\hline A. flavus & o & 4 & - & $3.3 \times 10^{5}$ \\
\hline A. flavus var. columnaris & o & I & $\ldots$ & $9.0 \times 10^{3}$ \\
\hline A. niger & 2 & I & $\mathrm{I} \cdot 3 \times \mathrm{IO}^{2}$ & $1 \cdot 3 \times 10^{2}$ \\
\hline A. petrakii & 0 & 3 & - & $3.0 \times 10^{3}$ \\
\hline A. wentii & I & 0 & $6.6 \times 10^{1}$ & - \\
\hline A. candidus & 3 & 18 & $6.0 \times 10^{2}$ & $2.5 \times 10^{6}$ \\
\hline Scopulariopsis brevicaulis & 10 & 17 & $2.7 \times 10^{3}$ & $7.8 \times 10^{7}$ \\
\hline Penicillium spp. & 30 & $2 \mathrm{I}$ & $2 \cdot 2 \times 10^{6}$ & $2.9 \times 10^{6}$ \\
\hline Absidia cylindrospora & 9 & 12 & $4.0 \times 10^{3}$ & $1 \cdot 2 \times 10^{4}$ \\
\hline Mucor racemosus & 2 & 6 & $6.0 \times 10^{2}$ & $8.0 \times 10^{3}$ \\
\hline Rhizopus oryzae & 3 & 3 & $6.0 \times 10^{2}$ & $4.0 \times 10^{4}$ \\
\hline Paecilomyces varioti & 20 & 2 & $8.6 \times 10^{4}$ & $2.0 \times 10^{3}$ \\
\hline Trichoderma viride & 7 & o & $6.0 \times 10^{3}$ & - \\
\hline T. hamatum & II & I & $1 \cdot 3 \times 10^{4}$ & $1.0 \times 10^{5}$ \\
\hline T. harzianum & 2 & 0 & $1 \cdot 3 \times 10^{3}$ & $\ldots$ \\
\hline T. koningii & 3 & o & $6.0 \times 10^{3}$ & -. \\
\hline Hyalodendron lignicola & 16 & o & $1 \cdot 7 \times 10^{6}$ & $\ldots$ \\
\hline Acremonium spp. & 6 & 2 & $8.6 \times 10^{4}$ & $\mathrm{I} \cdot \mathrm{O} \times \mathrm{IO}^{3}$ \\
\hline Cladosporium herbarum & 7 & 0 & $2.0 \times 10^{4}$ & - \\
\hline Phialophora fastigiata & 2 & o & $6.6 \times 10^{5}$ & - \\
\hline Graphium penicillioides & 4 & 0 & $6.0 \times 10^{4}$ & $\ldots$ \\
\hline Alternaria spp. & $\begin{array}{l}4 \\
\mathrm{I}\end{array}$ & 0 & $2.6 \times 10^{3}$ & - \\
\hline Stemphylium botryosum & I & o & $6.6 \times 10^{1}$ & - \\
\hline Fusarium sp. & I & 0 & $6.6 \times 10^{3}$ & - \\
\hline Sepedonium sp. & 0 & I & - & $7.0 \times 10^{4}$ \\
\hline Mycelia sterilia & I & o & $6.6 \times 10^{1}$ & - \\
\hline Basidiomycete & I & 0 & $4.6 \times 10^{4}$ & - \\
\hline Sphaeropsidales & 2 & 0 & $2 \cdot 1 \times 10^{5}$ & 一 \\
\hline Aureobasidium pullulans & 30 & 0 & $1.4 \times 10^{6}$ & — \\
\hline Yeast spp. & 29 & 19 & $3.5 \times 10^{7}$ & $1.9 \times 10^{7}$ \\
\hline Total mould count (mean) & 一 & - & $4.0 \times 10^{5}$ & $1.7 \times 10^{7}$ \\
\hline Bacteria $\left(37^{\circ} \mathrm{C}\right)$ & 30 & 20 & $\mathrm{I} \cdot \mathrm{I} \times 10^{7}$ & $9.5 \times 10^{9}$ \\
\hline Bacteria $\left(25^{\circ} \mathrm{C}\right)$ & $3 I$ & 24 & $3.8 \times 10^{7}$ & $1 \cdot 3 \times 10^{10}$ \\
\hline
\end{tabular}

Incidence denotes the number of samples from which each species was isolated.

Mucor racemosus occurred at similar frequencies in the initial and the final litter. The fungal species present in the final litter were thus closely similar to the species present in the dust at this time. The incidence of Aspergillus chevalieri, A. amstelodami, A. ruber, A. flavus, Absidia cylindrospora, Mucor racemosus, Circinella simplex, Botrytis cinerea, Cladosporium herbarum, Aureobasidium pullulans and yeast species increased in the dust during the growth of the birds. 
Table 2. Microbial flora of poultry litter and dust: final samples

The Penicillium species isolated from the litter included $P$. crustosum, $P$. chrysogenum, $P$. brevicompactum, $P$. roquefort $i, P$. diversum, $P$. corylophilum, $P$. frequentans, $P$. cyaneum, $P$. waksmani, $P$. biforme, $P$. lilacinum, $P$. variabile, while $P$. crustosum, $P$. chrysogenum, $P$. brevicompactum, $P$. roqueforti, $P$. corylophilum, $P$. corymbiferum, and $P$. steckii were isolated from the dust samples.

\begin{tabular}{|c|c|c|c|c|}
\hline & \multicolumn{2}{|c|}{ Incidence } & \multicolumn{2}{|c|}{ Maximum count/g } \\
\hline & Litter & Dust & Litter & Dust \\
\hline Total no. of samples & $31(19)$ & 30 & - & - \\
\hline \multicolumn{5}{|l|}{ Fungal species } \\
\hline Aspergillus sydowi & $23(\mathrm{IO})$ & 30 & $\begin{array}{c}1 \cdot 0 \times 10^{7} \\
\left(1 \cdot 1 \times 10^{7}\right)\end{array}$ & $1.7 \times 10^{7}$ \\
\hline A. versicolor & $8(5)$ & 10 & $\begin{array}{c}2.1 \times 10^{6} \\
\left(2.4 \times 10^{5}\right)\end{array}$ & $1.0 \times 10^{6}$ \\
\hline A. repens & $26(5)$ & 29 & $\begin{array}{c}6.0 \times 10^{5} \\
\left(5.0 \times 10^{5}\right)\end{array}$ & $1.7 \times 10^{7}$ \\
\hline A. amstelodami & 7 & 8 & $6.0 \times 10^{4}$ & $3.0 \times 10^{6}$ \\
\hline A. ruber & I6 (6) & I6 & $\begin{array}{c}\mathrm{I} \cdot 2 \times 10^{6} \\
\left(9.0 \times 10^{5}\right)\end{array}$ & $3.1 \times 10^{6}$ \\
\hline A. chevalieri & 15 & 24 & $2 \cdot 7 \times 10^{5}$ & $3.0 \times 10^{6}$ \\
\hline A. chevalieri var. intermedius & I & I & $2.0 \times 10^{4}$ & $3.0 \times 10^{5}$ \\
\hline A. flavus & 7 & I 2 & $1.5 \times 10^{4}$ & $5.0 \times 10^{5}$ \\
\hline A. flavus var. columnaris & 0 & 3 & - & $2.0 \times 10^{6}$ \\
\hline A. restrictus & I & 1 & $8.7 \times 10^{5}$ & $6.0 \times 10^{6}$ \\
\hline A. petrakii & 1 & 0 & $6.0 \times 10^{3}$ & - \\
\hline A. candidus & $26($ I 5$)$ & 25 & $\begin{array}{c}2.4 \times 10^{6} \\
\left(1.0 \times 10^{7}\right)\end{array}$ & $9.0 \times 10^{6}$ \\
\hline$A$, wentii & o & I & - & $1 \cdot 0 \times 10^{5}$ \\
\hline A. niger & 0 & I & - & $1 \cdot 0 \times 10^{4}$ \\
\hline Scopulariopsis brevicaulis & $30(18)$ & $2 I$ & $\begin{array}{c}1.4 \times 10^{6} \\
\left(1 \cdot 2 \times 10^{7}\right)\end{array}$ & $4.0 \times 10^{7}$ \\
\hline Paecilomyces varioti & 3 & 5 & $6.0 \times 10^{3}$ & $1.0 \times 10^{4}$ \\
\hline$P$. parvus & I & 0 & $6.0 \times 10^{4}$ & - \\
\hline Penicillium spp. & $2 I(I 2)$ & 29 & $\begin{array}{c}6.6 \times 10^{5} \\
\left(1.0 \times 10^{6}\right)\end{array}$ & $6.0 \times 10^{6}$ \\
\hline Absidia cylindrospora & 7 & 19 & $6.0 \times 10^{3}$ & $3.0 \times 10^{5}$ \\
\hline Mucor racemosus & I & I I & $6.0 \times 10^{2}$ & $1 \cdot 2 \times 10^{6}$ \\
\hline Circinella simplex & o & 4 & - & $1 \cdot 0 \times 10^{5}$ \\
\hline Rhizopus oryzae & 0 & 5 & - & $2.0 \times 10^{4}$ \\
\hline Botrytis cinerea & I & 5 & $6.0 \times 10^{2}$ & $1.0 \times 10^{5}$ \\
\hline Cladosporium herbarum & 3 & 6 & $4^{\circ} \mathrm{O} \times 10^{4}$ & $3.0 \times 10^{5}$ \\
\hline Acremonium spp. & 2 & o & $4.6 \times 10^{4}$ & $30 \times 10$ \\
\hline Chrysosporium keratinophilum & 0 & I & + & $1.0 \times 10^{3}$ \\
\hline Monascus ruber & 2 & 0 & $1 \cdot 0 \times 10^{2}$ & $\ldots$ \\
\hline Alternaria spp. & 2 & 2 & $2.0 \times 10^{4}$ & $4.0 \times 10^{4}$ \\
\hline Aureobasidium pullulans & 0 & 3 & - & $7.0 \times 10^{4}$ \\
\hline Yeast spp. & $24(13)$ & 30 & $\begin{array}{c}3.5 \times 10^{7} \\
\left(4.0 \times 10^{8}\right)\end{array}$ & $6.0 \times 10^{7}$ \\
\hline Total mould count (mean & - & 一 & $\mathrm{I} \cdot 9 \times 10^{6}$ & $2.2 \times 10^{7}$ \\
\hline Bacteria $\left(37^{\circ} \mathrm{C}\right)$ & $3 I$ & 30 & $1.5 \times 10^{10}$ & $8.2 \times 10^{9}$ \\
\hline Bacteria $\left(25^{\circ} \mathrm{C}\right)$ & $3 I$ & 30 & $I \cdot 1 \times 10^{10}$ & $9.6 \times 10^{9}$ \\
\hline
\end{tabular}

Incidence denotes the number of samples from which each species was isolated. Figures in parentheses show the incidence and maximum counts for the predominant fungi isolated from 19 samples of litter, associated with musty birds, examined previously. 
Although the maximum mould count in the initial and final samples of litter ranged between $10^{5}$ and $10^{7} / \mathrm{g}$, many samples had a much lower count for most of the species. This is in contrast with the counts for the dust samples, which showed less variability.

Samples of the final litter associated with musty birds (Curtis et al. 1972) had a similar fungal flora to the present final litter samples in that Scopulariopsis brevicaulis, Penicillium spp. and Aspergillus spp. were the predominant fungi (Table 2). Although fewer Aspergillus spp. were isolated and a lower incidence of $A$. repens and $A$. ruber recorded, the maximum counts of the species present were of the same order as those in the present survey.

The moisture levels of the fresh shavings ranged from $9.0 \%$ to $26.0 \%$, although the majority of samples varied between $11.0 \%$ and $18.0 \%$. The used litter samples generally had a higher moisture content ranging from $19.0 \%$ to $38.0 \%$, with the majority between $25.0 \%$ and $32.0 \%$.

\section{DISCUSSION}

The fungal floras of the present samples of litter were remarkably uniform, and consistently showed a complete change after the growth of the birds on the litter. Lovett et al. (197I) did not observe a change in composition of the fungal population after the growth of the birds, and, although they report a high incidence of Scopulariopsis, Aspergillus spp. appear to be predominant in the present litter samples. Detailed comparison with their results cannot be made because they did not distinguish the various species of fungi. The number of bacteria in the used litters was of the same order as that reported by Lovett et al. (I97I), Halbrook et al. (I95I), and Schefferle (I965).

Most samples of shavings derived from imported timber contain chlorophenols (Parr et al. unpublished). The microbiological methylation to the corresponding chloroanisoles has been shown to occur in poultry litter and in pure cultures of Aspergillus sydowi, Penicillium crustosum and Scopulariopsis brevicaulis isolated from poultry litter (Curtis et al. 1972). Other fungi and bacteria in the litter may be capable of methylating chlorophenols, but their role has not yet been investigated.

Analysis of litter samples from the present survey showed that there was a marked decrease in the concentrations of both 2,3,4,6-tetra- and pentachlorophenol in the litter during the growth of the birds (Parr et al. unpublished). Some of the final litter samples in the present survey had a distinctly musty odour, and a slight musty odour could be detected in at least $50 \%$ of the samples. In $83 \%$ of the samples $2,3,4,6$-tetrachloroanisole was detected (Parr et al. unpublished); the concentrations varied considerably and the greatest was $3.6 \mu \mathrm{g} / \mathrm{g}$ whereas the experience in this laboratory is that tainted birds are associated only with concentrations of $5 \mu \mathrm{g} / \mathrm{g}$ or above. We have found no major difference between the fungal flora of litter giving rise to musty birds, and of litter containing concentrations of tetrachloroanisole lower than $5 \mu \mathrm{g} / \mathrm{g}$. Mustiness in broiler chickens may occur only when there is a relatively high concentration of chloroanisoles in the litter immediately prior to harvesting of the birds. Such concentrations may be localized in a hut and be transient owing to the volatility of the chloroanisoles. It is unlikely that chloroanisoles are derived other than from the corresponding chlorophenols in the litter.

Some of the more numerous fungi found in the litters, notably certain species of Aspergillus and Penicillium, are potential mycotoxin producers. Some strains of Scopulariopsis have also been shown to produce toxic metabolites (Christensen, Nelson, Mirocha \& Bates, I968; Martin, Gilman \& Keen, I970; Lovett, 1972). Martin et al. (1970) reported a strain of $S$. brevicaulis to be toxic to ducklings. Although production of such toxins in the litter has not been proved, Lovett (1972) drew attention to the importance of this potential in the light 
of the proposed use of poultry-house litter as a nitrogen source in livestock feeds (Walters, 1972).

Wood shavings initially have a low moisture content $(9.0 \%$ to $26.0 \%)$. It is therefore significant that they should contain a number of species of the Aspergillus glaucus group (A. repens, $A$. ruber, A. amstelodami and $A$. chevalieri) which are characteristic of low moisture environments, and have been shown to initiate growth at low water activities (Snow, I949; Scott, I957; Ayerst, 1969). Semeniuk, Nagel \& Gilman (1947), in their report on the development and deterioration of stored yellow dent shelled corn, state that the real importance of the A. glaucus group, along with the $A$. restrictus group, lies in their ability to initiate growth at minimum moisture levels, thus facilitating the invasion of slightly less xerophilic moulds, such as $A$. candidus, $A$. versicolor, $A$. flavus, and certain species of Penicillium, as additional water is released by their metabolic activities.

The fungal floras of both initial and final dust samples were similar to that of the final litter. Environmental conditions in the poultry houses appear to favour the development of organisms present in the dust rather than those present on the shavings initially. We have examined samples of feed for the presence of fungi and, contrary to the findings of Lovett et al. (197I), found no significant mould contamination. It would be impractical to remove all the dust from a broiler house during the routine cleaning between rearing cycles; observations from the present survey suggest that this dust is the major source of inoculum for each batch of fresh shavings.

The authors thank Dr J. L. Peel for discussion and criticism of the manuscript, Miss M. E. Flegg for expert technical assistance, and Mrs M. G. Tulloch of the Commonwealth Mycological Institute for help with the identification of some of the Penicillium spp.

\section{REFERENCES}

AYERST, G. (1969). The effects of moisture and temperature on growth and spore germination in some fungi. Joumal of Stored Products Research 5, I 27-141.

Christensen, C. M., Nelson, G. H., Mirocha, C. J. \& Bates, F. (I968). Toxicity to experimental animals of 943 isolates of fungi. Cancer Research 28, 2293-2295.

Curtis, R. F., Land, D. G., Griffiths, N. M., Gee, M. G., Robinson, D., Peel, J. L., Dennis, C. \& Gee, J. M. (I972). 2,3,4,6-Tetrachloroanisole; association with musty taint in chickens and microbiological formation. Nature, London 235, 223-224.

Halbrook, E. R., Winter, A. R. \& Sutton, T. S. (I95I). The microflora of poultry house litter and droppings. Poultry Science $30,38 \mathrm{I}-388$.

LovetT, J. (1972). Toxigenic fungi from poultry feed and litter. Poultry Science 5I, 309-3I 3.

Lovett, J., Messer, J. W. \& Read, R. B., JUN. ( 1971). The microflora of Southern Ohio poultry litter. Poultry Science 50, 746-75I.

Martin, P. M. D., Gilman, G. A. \& Keen, P. (I97I). The incidence of fungi in foodstuffs and their significance based on a survey in the Eastern Transvaal and Swaziland. Symposium on Mycotoxins in Human Health, pp. 28I-289. Edited by I. F. H. Purchase, London: Macmillan.

SChEFfERLE, H. E. (1965). The microbiology of built up poultry litter. Journal of Applied Bacteriology $\mathbf{2 8}$, 403-4II.

Scott, W. J. (1957). Water relations of food storage microorganisms. Advances in Food Research 7, 83-1 27.

Semeniuk, G., Nagel, C. M. \& Gilman, J. C. (1947). Observations on mold development and on deterioration in stored yellow dent shelled corn. lowa State College, Agricultural Experimental Station Bulletin 349, 253-284.

SNow, D. (1949). The germination of mould spores at controlled humidities. Annals of Applied Biology 36, I-I3.

WAlters, J. (1972). Disposal or utilization of waste; manure for feed. Poultry World 123, 20-22. 